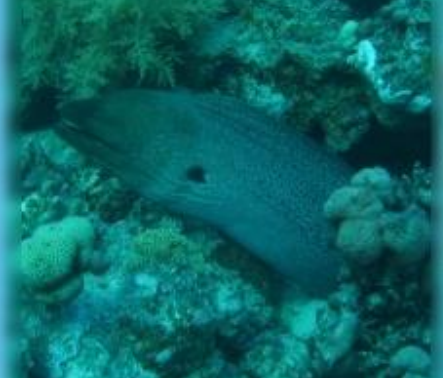

\title{
A REVIEW ON GROWTH OF SOME DIPLODUS SPECIES DISTRIBUTED WORLDWIDE
}

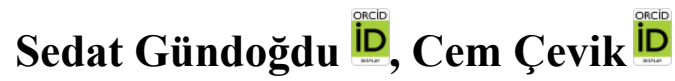

\section{Cite this article as:}

Gündoğdu S., Çevik, C. (2018). A Review on Growth of Some Diplodus Species Distributed Worldwide. Aquatic Research, 1(2), 86-102. DOI: $10.3153 / A R 18010$

${ }^{1}$ Çukurova University, Faculty of Fisheries, Department of Basic Sciences, 01330, Sarıçam, Adana, Turkey

Submitted: 20.02 .2018

Accepted: 07.03.2018

Published online: 08.03.2018

Correspondence:

Sedat GÜNDOĞDU

\section{E-mail:}

sgundogdu@cu.edu.tr

\section{ABSTRACT}

Estimation of the growth parameters of fish are vital to understand their biology. For this purpose we collected studies that performed up to 2017 regarding the growth of species belonging to the Diplodus genus. Data were gathered from sources like Web of Science (webofknowledge.com), Scopus (scopus.com), Google Scholar (scholar.google.com), Researchgate (researchgate.com) and Academia (academia.edu). 79 datasets from 52 different studies belongs to 10 species were compiled. Reviewed studies were published between 1982 - 2017 and were performed in 26 different regions. It was determined that the most frequently studied species was $D$. vulgaris $(\mathrm{n}=23)$. Among growth parameters, it was determined that there is a negative relationship between $K$ and $L_{\infty}$, and $K$ and $t_{\max }$, there is a positive relationship between $L_{\infty}$ and $L_{\max }$. It was also found that there is a negative relationship between $K$ and $L_{\infty}$ vs latitude.

Keywords: Growth, Diplodus, Population dynamics, Life history parameters 


\section{Introduction}

The Diplodus genus, distributed all around the world, have a significant economic importance (Gordoa and Moli, 1997; Pajuelo and Lorenzo, 2004; Soykan et al., 2015). Due to varied habitat preferences, these species can be found in different marine ecosystems such as rocky habitats and sandy bottoms. According to Fishbase, 21 species of this genus can be found in world seas (Froese and Pauly, 2017). While the main area of distribution for these species is the Mediterranean Sea and the Atlantic Ocean, they are also found in the Caribbean, Gulf of Mexico, the Indian Ocean, the Red Sea and the Persian Gulf (Figure 1, Sala and Ballesteros, 1997; Summerer et al., 2001; Froese and Pauly, 2017). Along with being a main target species for small scale, semi-industrial fisheries and sport fishing, a couple species belonging to this genus are also important with regards to aquaculture (Reina et al., 1994; Summerer et al., 2001). For this reason, their biology and population dynamics are essential.

While there are many studies regarding various biological characteristics of Diplodus species, studies conducted on age and growth are only available for 10 species (Appendix 1). Evaluating different species belonging to the same genus that show similar morphological and growth characteristics together offers significant advantages regarding population dynamics (Hilborn and Liermann, 1998; Helser et al., 2007). Compilation and reanalysis of growth studies help us for better understanding the changes in growth characteristics (Pilling et al., 2002; Helser and Lai, 2004; Helser et al., 2007). For this purpose the aim of this study is to gather agegrowth studies performed on species belonging to Diplodus genus and to establish the variability in growth between species and regions. Finally, growth variety between species was addressed based on the relationships between growth parameters.

\section{Compilation of Data from References}

Studies performed up to 2017 regarding the growth of species belonging to the Diplodus genus (Figure 2) were gathered from sources like Web of Science (www.webofknowledge.com), Scopus (www.scopus.com), Google Scholar (www.scholar.google.com), Researchgate (www.researchgate.com) and Academia (www.academia.edu). Collected studies were carefully classified and necessary information was extracted (See appendix). This information includes the following: the location the study (latitude, longitude), length type (LT), $L_{\infty}, K, t_{0}$, maximum age $\left(t_{\max }\right)$, minimum and maximum length $\left(L_{\min }\right.$, $L_{\max }$ ), sex, age determination method (otolith reading (OR), scale reading (SR), length frequency method (LF)), sample size $(\mathrm{N})$ and the year the study was performed (see Appendix).

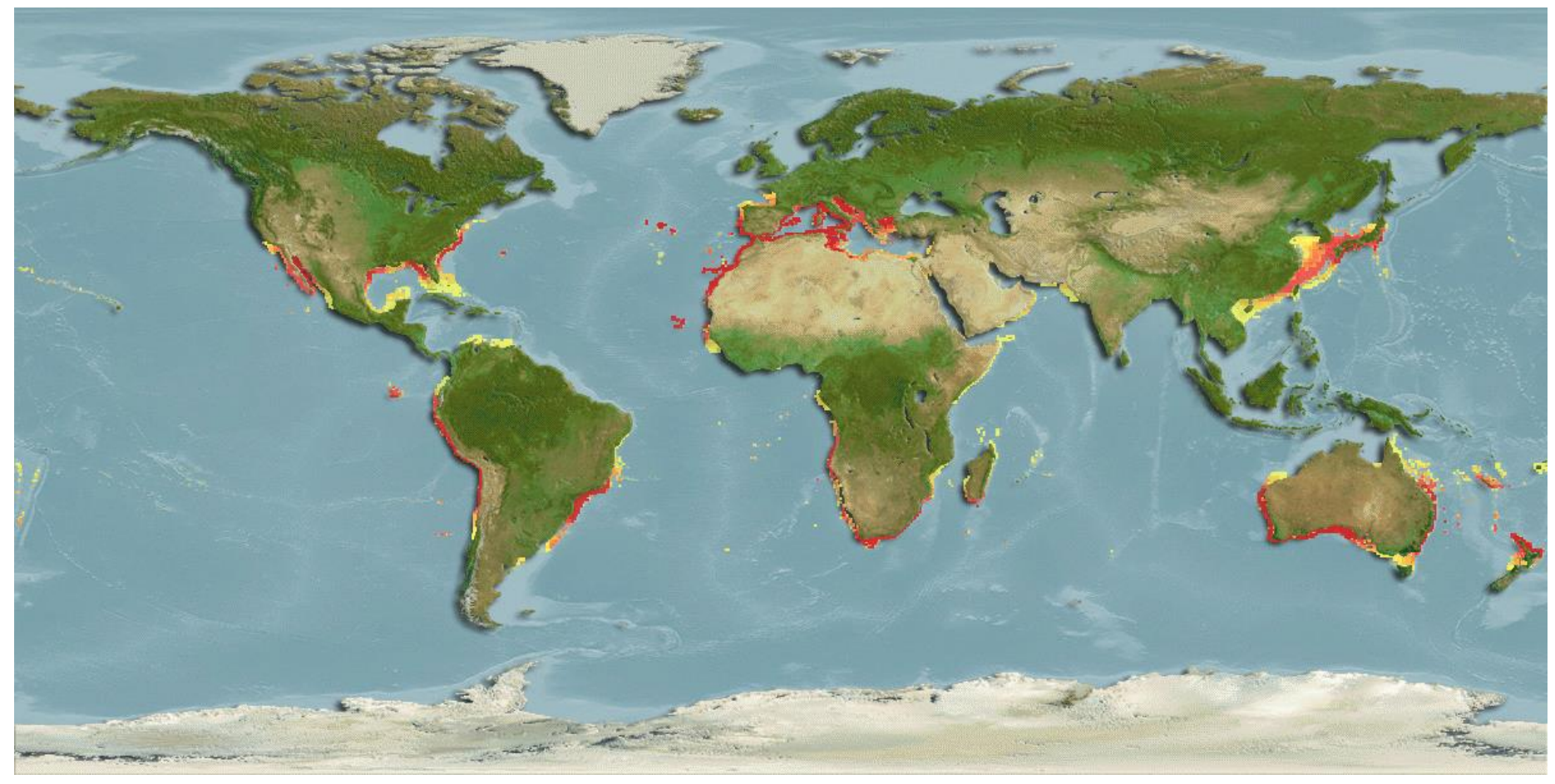

Figure 1. Distribution of the Diplodus genus (Fishbase 2017). 


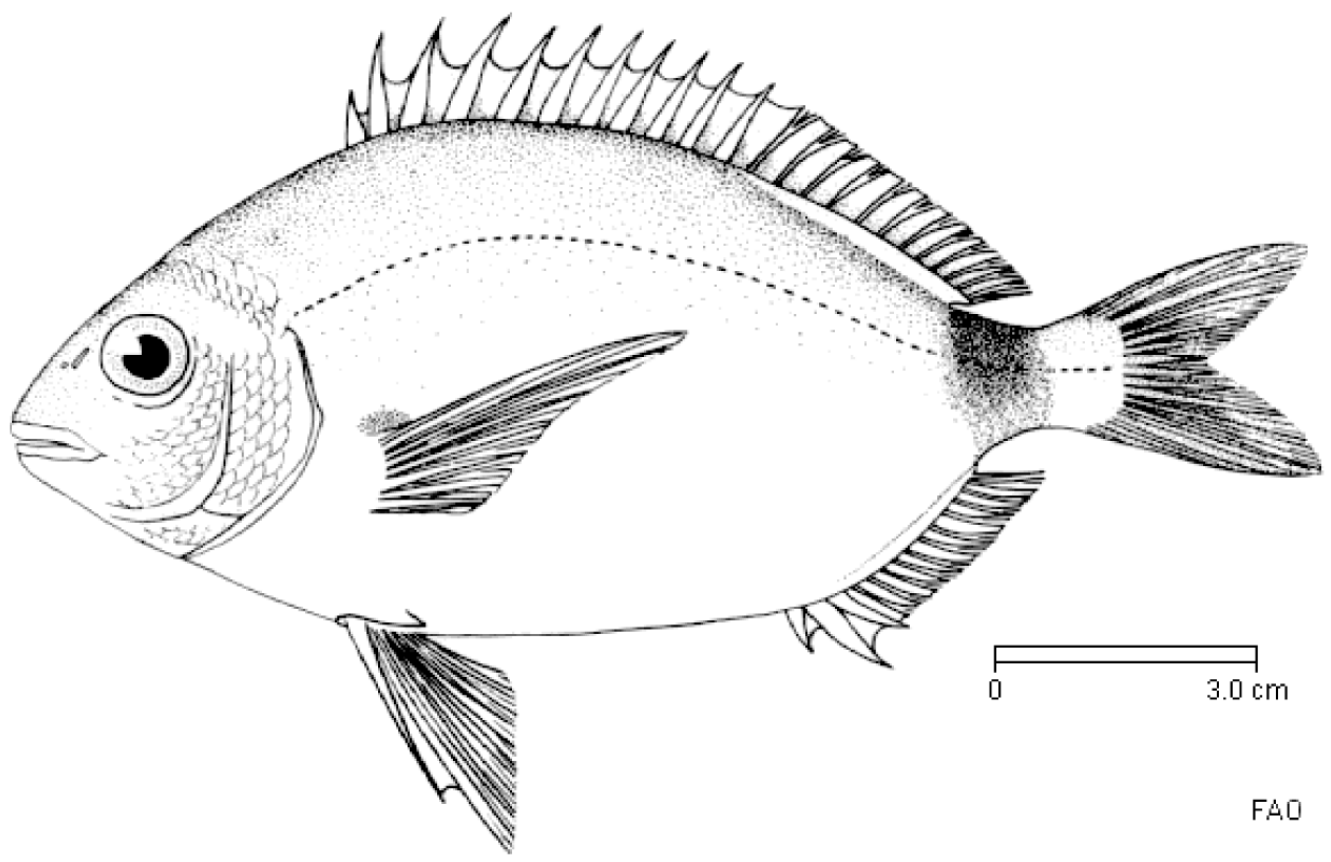

Figure 2. General appearance of Diplodus (Diplodus annularis, Source: Bauchot, (1987)

In cases where the studies compiled used different size types, the size-size relationship formula for the species involved presented in Fishbase (Froese and Pauly, 2017) was used for all size groups and $L_{\min }, L_{\max }$ and $L_{\infty}$ values were transformed (Stergiou and Karachle, 2006; Froese, 2006; Gündoğdu and Baylan, 2016; Gündoğdu et al., 2016). For species where fork lengths were reported and to convert the fork lengths given to total length, the following formula taken from Fishbase (Froese and Pauly, 2017) were used.,

D. annularis: $\mathrm{TL}=0+1.09 \mathrm{FL}$

D. bellottii: $\mathrm{TL}=0+1.093 \mathrm{FL}$

D. capensis: $\mathrm{TL}=0.2554+1.163 \mathrm{FL}$

D. hottentatus: $\mathrm{TL}=0.2628+1.161 \mathrm{FL}$

D. sargus sargus: $\mathrm{TL}=0+1.088 \mathrm{FL}$

D. vulgaris: $\mathrm{TL}=0+1.15 \mathrm{FL}$

For studies where maximum length was not reported, if present the $L_{\max }$ value given in other studies from the same region, and if not the average $L_{\max }$ value given in Fishbase was used

In literature, fish growth is mostly expressed based on the von Bertalanffy growth model. Since this was the case for all literature collected, the parameters used in this model were taken directly without any recalculations. Latitude and longitude information for the study areas given in gathered studies were reproduced as averages. This way, the same latitude and longitude information is given for studies performed in the same area. It was thought that if done otherwise, taking close latitudes and longitudes for studies performed in the same area would increase the difficulty of the analysis and reduce the significance of the results.

The change of growth parameters and other life history parameters taken from the compiled studies relative to each other and latitude was analyzed using the Tableau 10.0 software. Separate and joint growth formula of all species were recalculated using the median values of all parameters and regression constants (slope) were analyzed using an independent sample t-test with SPSS v20 package software.

\section{Assessment of Data and Discussion}

79 datasets from 52 different studies were compiled in this study. This data set belongs to 10 different species. Studies were published between $1982-2017$ and were performed in 26 different regions (Figure 3; Appendix 1).

Most studies were from around Canary Islands $(n=14,18 \%)$. Gathered studies are most frequently on the biology of $D$. vulgaris $(\mathrm{n}=23,29 \%), D$. annularis $(\mathrm{n}=17,22 \%)$ and $D$. sargus sargus $(\mathrm{n}=15,19 \%)$ species (Appendix 1). Age reading method was used in 71 studies (otolith reading in 45, scale reading in 26), while in 6 studies estimation was done using 
the length frequency method, and in 2 studies no information regarding this was given. Length measurements were done as total length $(n=65)$ and fork length $(n=14)$. It was determined that there was a significant amount of variation between number of observations in studies where growth parameter estimations were performed. In 7 estimates, $>1000$ individuals were used, while in 59 estimates the number of individuals used was $<1000$. It was determined that in 10 data sets the number of observations was not reported (Figure 4).

$t_{\max }$ value (1 year to 33 years) was reported in 71 data sets and $L_{\max }$ value $(9,3 \mathrm{~cm}$ to $56,5 \mathrm{~cm})$ was reported in 69 data sets. $K, L_{\infty}$ and $t_{0}$ values were reported in all studies (Appendix 1). It was determined that the $K$ value varied between 0.073 year $^{-1}$ and 0,56 year $^{-1}$, the $L_{\infty}$ value varied between $13.32 \mathrm{~cm}$ and $68.83 \mathrm{~cm}$ and $t_{0}$ value varied between -5.33 years and $-0,02$ years (Table 1 ).
It was determined that the $L_{\max } / L_{\infty}$ ratio varied between 0.52 and 1.84 for all studies, with an average of 0.95 (Table 1). The relationship between $L_{\max }$ and $L_{\infty}$ was calculated together for all species and a positive and statistically significant correlation was discovered between them $(r=0.827$, $P<0.05, L_{\infty}=4.42+0.95 * L_{\text {max }} ;$ Figure 4$)$. It was determined that the relationship between $t_{\max }$ and $K$ is negative and statistically significant $(r=-0.41, P<0.05, \operatorname{Ln}(K)=$ $-0.72-0.38 * \operatorname{Ln}\left(t_{\max }\right)$; Figure 5$)$. It was also determined that the relationship between $K$ and $L_{\infty}$ is negative and statistically significant $(r=-0.71, P<0.05, \operatorname{Ln}(K)=1.66-$ $0.92 * \operatorname{Ln}\left(L_{\infty}\right)$; Figure 5$)$.

The relationship between latitude and von Bertalanffy parameters was determined to be negative for $K$ and $L_{\infty}$, and positive for $\mathrm{t}_{0}$ (Figure 6). However, the relationships for all three parameters were found to be statistically insignificant (t-test, $P>0.05$; Figure 6).

Table 1. Descriptive statistics of the parameters belonging to the compiled studies

\begin{tabular}{lccccc}
\hline \multicolumn{1}{c}{ Parameters } & Mean & Std.Error & Minimum & Median & Maximum \\
\hline$K$ & 0.24 & 0.01 & 0.07 & 0.21 & 0.56 \\
$L_{\infty}$ & 35.3 & 1.48 & 13.32 & 33.3 & 68.8 \\
$t_{0}$ & -1.31 & 0.11 & -5.33 & -0.98 & -0.02 \\
$L_{\max }$ & 32.6 & 1.29 & 9.30 & 32.0 & 56.5 \\
$t_{\max }$ & 10.0 & 0.60 & 1.00 & 9.00 & 33.0 \\
$L_{\max } / L_{\infty}$ & 0.95 & 0.02 & 0.52 & 0.93 & 1.84 \\
\hline
\end{tabular}

Table 2. Recalculated models using the median values taken from the compiled studies

\begin{tabular}{lc}
\hline Species & Estimated Model \\
\hline D. annularis & $L_{t}=\left(20.37 *\left(1-e^{-0.25(t+0.89)}\right)\right)$ \\
D. bellottii & $L_{t}=\left(28.42 *\left(1-e^{-0.27(t+0.19)}\right)\right)$ \\
D. capensis & $L_{t}=\left(27.7 *\left(1-e^{-0.31(t+1.05)}\right)\right)$ \\
D. cervinus & $L_{t}=\left(60.9 *\left(1-e^{-0.15(t+0.76)}\right)\right)$ \\
D. holbrooki & $L_{t}=\left(33.28 *\left(1-e^{-0.24(t+0.99)}\right)\right)$ \\
D. hottentotus & $L_{t}=\left(46.24 *\left(1-e^{-0.15(t+2.15)}\right)\right)$ \\
D. puntazzo & $L_{t}=\left(36.84 *\left(1-e^{-0.2(t+0.98)}\right)\right)$ \\
D. sargus cadenati & $L_{t}=\left(47.65 *\left(1-e^{-0.14(t+1.98)}\right)\right)$ \\
D. sargus sargus & $L_{t}=\left(40.71 *\left(1-e^{-0.18(t+0.86)}\right)\right)$ \\
D. vulgaris & $L_{t}=\left(33.3 *\left(1-e^{-0.22(t+0.96)}\right)\right)$ \\
Total & $L_{t}=\left(33.3 *\left(1-e^{-0.21(t+0.98)}\right)\right)$ \\
\hline
\end{tabular}




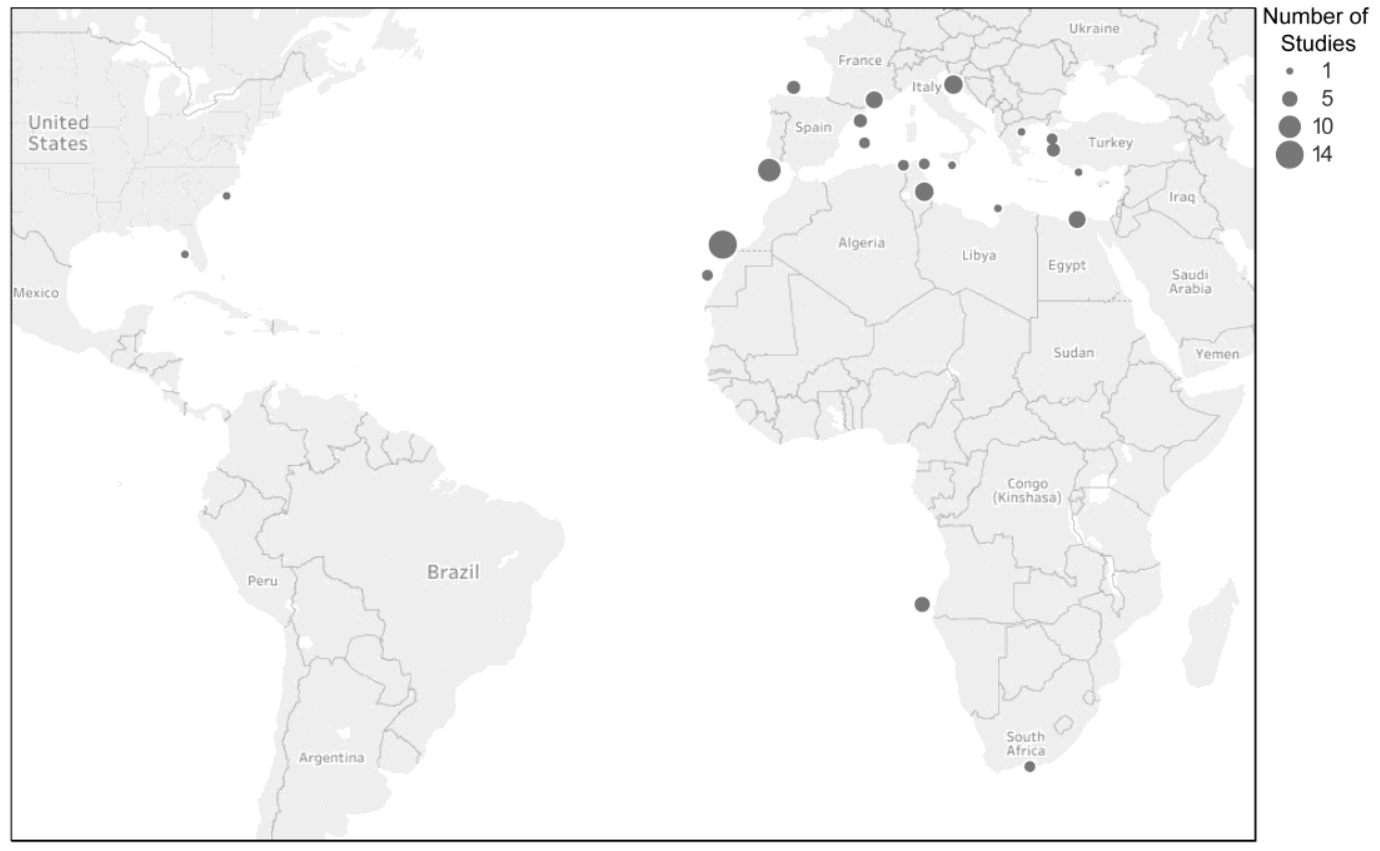

Figure 3. The distribution of the compiled studies

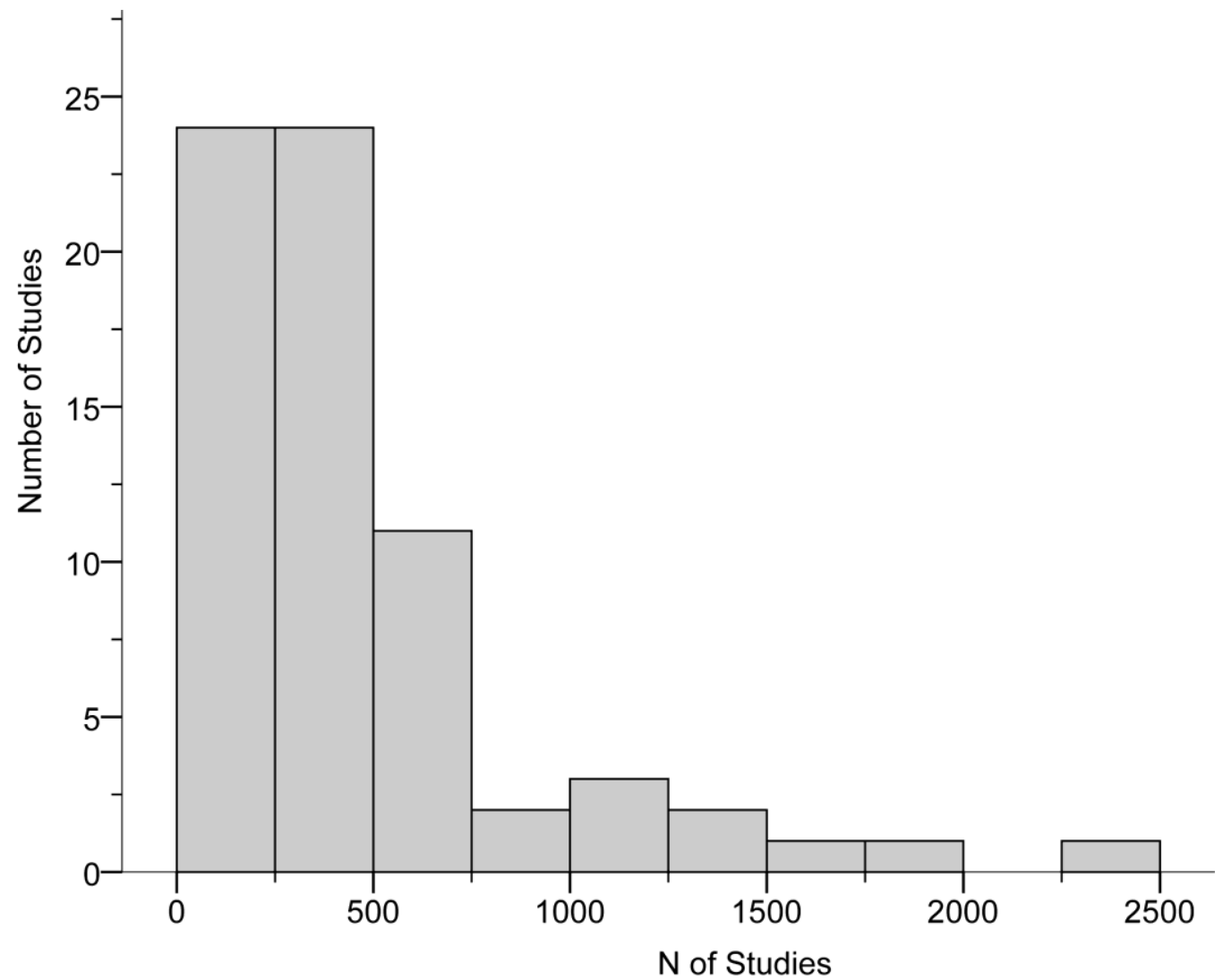

Figure 4. Frequency distribution of the sample sizes on which the biological parameters presented here were based (see Appendix 1). 
The growth formula created based on the median values calculated using the entire data set is given in table 2. Estimated growth curves created with the help of these shared formulas are given in figure 7. As seen in figure 7, for the first three years, all species except for $D$. annularis demonstrate similar growth. It was seen that curves that match the initially rapid and later slowing growth with age posited in the general fish growth theory.

In this study, 52 studies performed in different regions around the world that include the biological parameters of 10 different species belonging to the Diplodus genus (Appendix 1). This study is one of the rare studies that considers the growth of the entirety of a certain genus at once, and it is the first study that considers the species belonging to the Diplodus genus together. Another similar study was performed by Helser et al. (2007) for the Sebastes genus, found in the Pacific Ocean. All studies other than our study and the Helser et al. (2007) study are studies where the growth parameters of more than one genus and species were considered together. These are Pauly (1978), Pauly (1980), Paul (1992), Stergiou (2000), Frisk et al. (2001), Stergiou and Karachle (2006), Apostolidis and Stergiou (2012), Apostolidis and Stergiou (2014) and Gündoğdu and Baylan (2016).

Aside from coloring, fish belonging to the Diplodus genus show similarities regarding many characteristics and have similar habitat demands (Summerer et al., 2001). This causes their feeding habits to be similar as well (Ventura et al., 2015). For this reason, considering the growth characteristics of fish belonging to the Diplodus genus together and in a comparative manner is quite reasonable.

Growth is the most studied subject, as it affects many life history parameters and involves a lot of basic information for fishing management (Helser and Lai, 2004). However, as stated above, the number of studies that consider different populations belonging to the same species or genus in a comparative manner is quite limited. Consequently, this study attempts to establish the relationship between various biological parameters and between some parameters and latitude through the compiled studies. Among these relationships, one of the most important is the relationship between $K$ and $L_{\infty}$. It is known that there's a negative relationship between these two parameters (Beverton and Holt, 1959; Adams, 1980; Pauly, 1980; Munro and Pauly, 1983; Pauly and Munro, 1984; Wootton, 2012). The negative correlation (0.71) found in this study matches this general assumption (Figure 5). However, despite the presence of this negative relationship, in reality there's no direct evidence in natural populations regarding this negative correlation (Pilling et al., 2002; Helser and Lai, 2004). It is thought that the negative relationship between these two parameters arises from the mathematical nature of the von Bertalanffy growth model (Stergiou, 2000). The negative relationship between the $K$ value and the $t_{\max }$ value $(-0.41)$ was found to be similar to the value found in a multi-species study performed by Stergiou and Karachle (2006) (-0.37). If we consider Taylor (1958)'s $K=3 / t_{\max }$ equation a general equation, it can be seen that this study has a result that is close to this value (Table 1).

$L_{\max } / L_{\infty}$ ratio $(0.95)$ and the correlation between them $(0.82)$ was found to be similar to the studies performed among different species (Stergiou and Karachle, 2006 (0.99); Apostolidis and Stergiou, 2014 (0.87); Gündoğdu and Baylan, $2016(0.96))$. And this shows that there's a relationship between these two parameters in general terms that is independent of species (Froese and Binohlan, 2000). Taylor (1958), Pauly and Munro (1984) and Froese and Binohlan (2000) state that fish usually live for $95 \%$ of the $L_{\infty}$ value. And this shows that there's a relationship like $L_{\infty} \approx$ $L_{\max } / 0.95$ between these two parameters, which fits the results we have found in this study.

Helser and Lai (2004) state that there's a relative relationship between growth parameters and latitude that is independent of statistical significance. According to this, $K$ and $L_{\infty}$ have a negative relationship with latitude, while $t_{0}$ has a positive relationship. Our findings are in the same direction. When Figure 6 is examined, it can be seen that $K$ and $L_{\infty}$ values have a negative relationship with latitude, while $t_{0}$ value has a relatively positive relationship.

Feeding habits, genetic relationships, food available in the environment, competition and temperature are the basic factors that determine the growth performance of a species (Jobling, 1981; Helser et al., 2007). For this reason, growth trends of species that are similar to each other with regards to these factors would be similar as well. Consequently, the results expressed in table 2 and figure 7 support this conclusion. The mtDNA based relationship study performed by Summerer et al. (2001) on the Diplodus genus partially supports the estimated growth model curves we have presented here. Moreover, in Summerer et al. (2001)' study, D. cervi$n u s$ in a different cluster than other species. Similarly, $D$. annularis and other Diplodus species are considered separate to a point. Furthermore, the same reports put all species other than D. annularis and D. cervinus in $D$. sargus clades (Figure 8). 

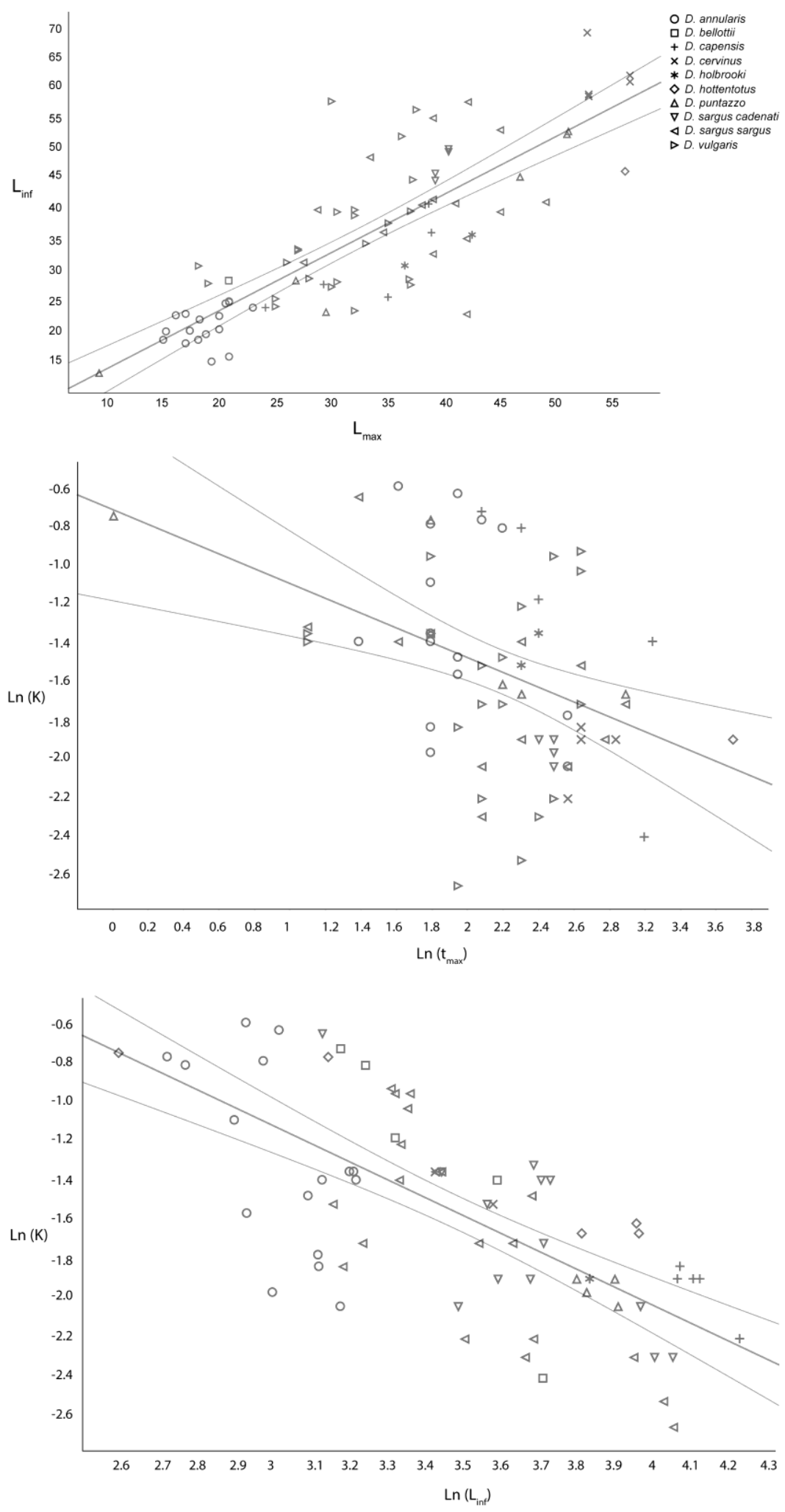

Figure 5. Relationships between von Bertalanffy growth parameters ( a- $L_{\infty}$ vs $L_{\max }$, b- $\ln (K)$ vs $t_{\max }, \mathrm{c}-\ln (K)$ vs $\left.\mathrm{t}_{0}\right)$ and the fitted curves belonging to those. The middle curve in each graph represents the fitted curve, and the other two represent the $95 \%$ confidence limits. 

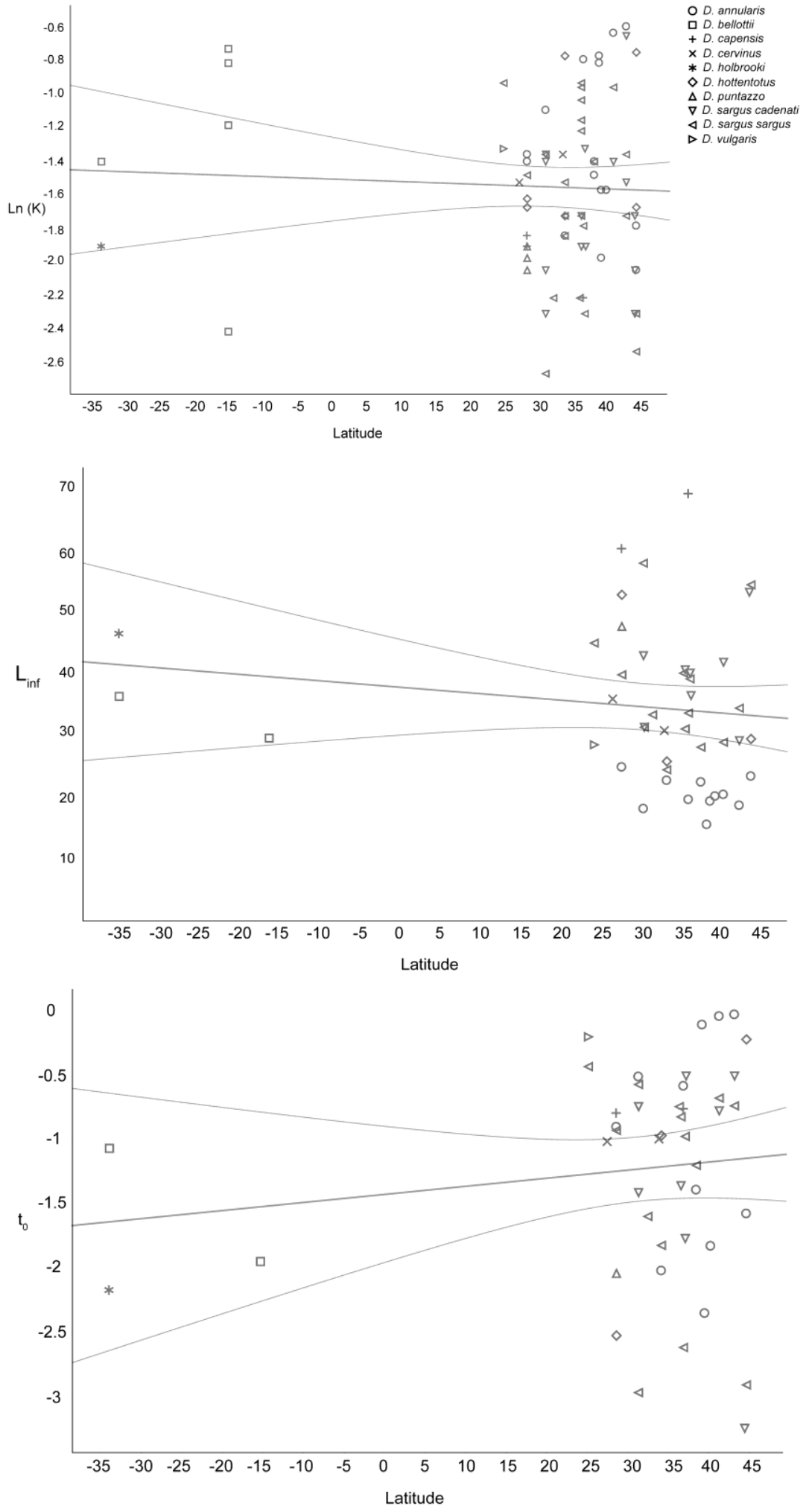

Figure 6. Relationships between growth parameters and latitude and the fitted curves belonging to those. The middle curve in each graph represents the fitted curve, and the other two represent the $95 \%$ confidence limits. 


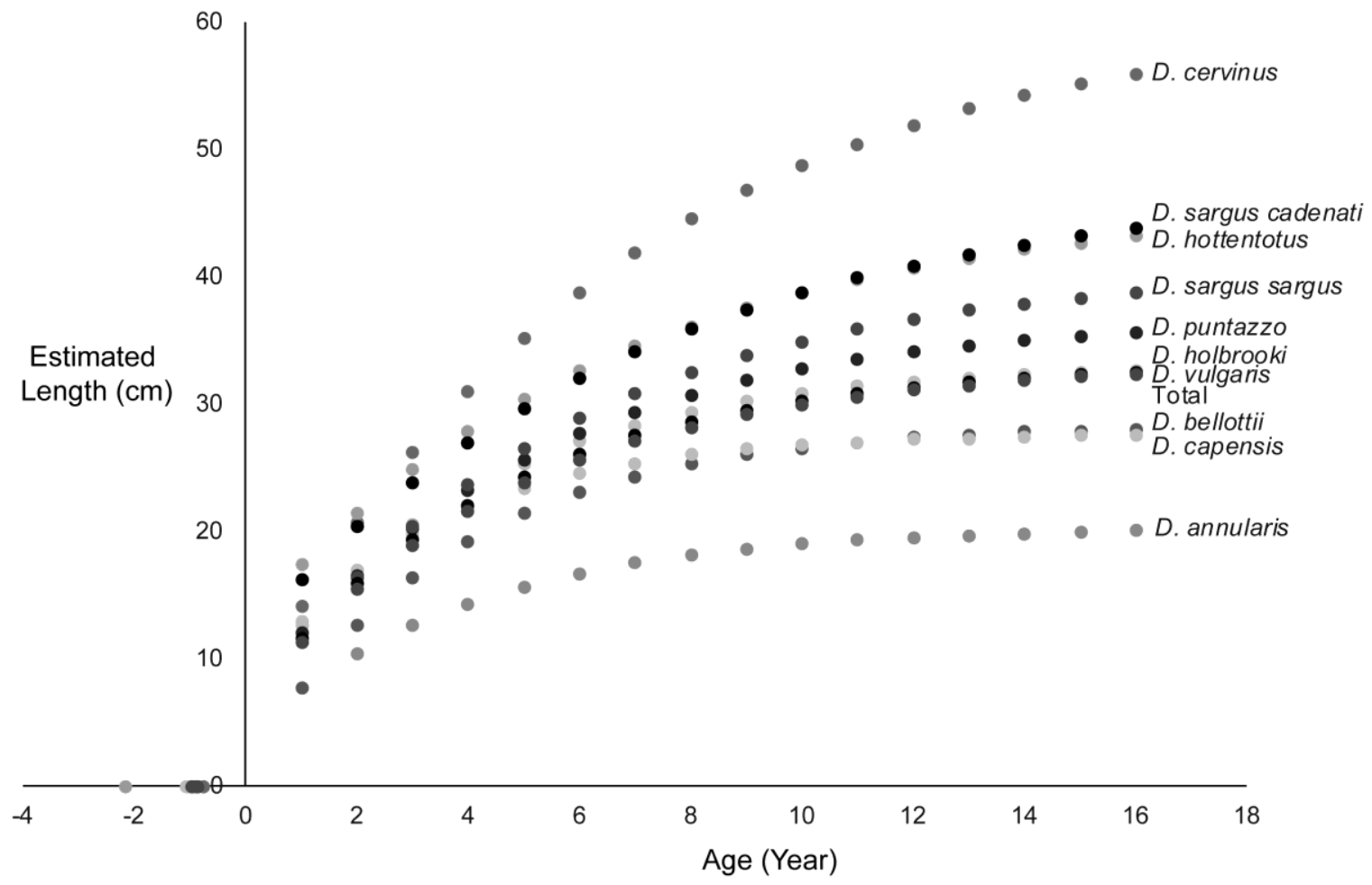

Figure 7. Estimated age-length curves the new models based on the median values provided

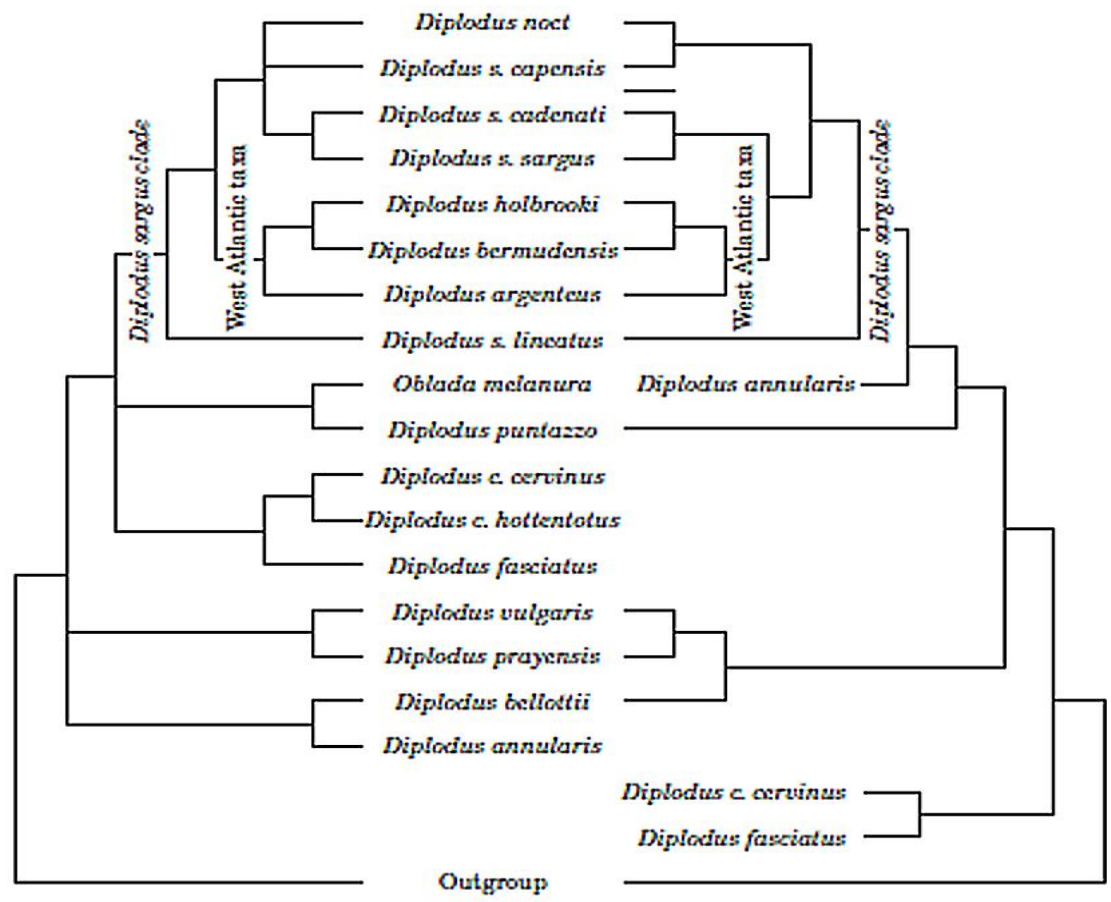

Figure 8. Relationship between genetic characteristics and morphology of genus Diplodus. The mtDNA (left) and morphological (right) comparison of species belonging to the Diplodus genus (Taken from Summerer et al. (2001). 


\section{Conclusion}

Establishing the variation of growth parameters between populations and species is to key for ecological studies. Comparing growth models and parameters both systematically and over other variables would help us in understanding the growth characteristics of the genus and species involved. Comparative studies like these carry great significance to understand the biology of species that can be considered target species for fishing.

\section{References}

Adams, P.B. (1980). Life history patterns in marine fishes and their consequences for fisheries management. Fishery Bulletin, 78(1), 1-12.

Apostolidis, C., Stergiou, K.I. (2016). Diversity and geographic coverage of growth studies of Mediterranean fishes.. In: 10th Panhellenic Symposium of Oceanography and Fisheries, (pp: 7). 10-11 May 2012, Athens, Greece.

Apostolidis, C., Stergiou, K.I. (2014). Estimation of growth parameters from published data for several Mediterranean fishes. Journal of Applied Ichthyology, 30(1), 189-194.

Beverton, R.J.H., Holt, S.J. (1959). A review of the lifespans and mortality rates of fish in nature, and their relation to growth and other physiological characteristics. In Ciba Foundation Symposium-The Lifespan of Animals (Colloquia on Ageing), Volume 5 (pp. 142180). John Wiley \& Sons, Ltd.

Frisk, M.G., Miller, T.J., Fogarty, M.J. (2001). Estimation and analysis of biological parameters in elasmobranch fishes: a comparative life history study. Canadian Journal of Fisheries and Aquatic Sciences, 58(5), 969981.

Froese, R. (2006). Cube law, condition factor and weightlength relationships: history, meta-analysis and recommendations. Journal of Applied Ichthyology, 22(4), 241-253.

Froese, R., Binohlan, C. (2000). Empirical relationships to estimate asymptotic length, length at first maturity and length at maximum yield per recruit in fishes, with a simple method to evaluate length frequency data. Journal of Fish Biology, 56(4), 758-773.
Froese, R., Pauly, D. (2017). FishBase 2017, version (march, 2017). World Wide Web electronic publication Home page at: http://www.fishbase.org

Gordoa, A., Molí, B. (1997). Age and growth of the sparids Diplodus vulgaris, D. sargus and D. annularis in adult populations and the differences in their juvenile growth patterns in the north-western Mediterranean Sea. Fisheries Research, 33(1-3), 123-129.

Gündoğdu, S., Baylan, M. (2016). Analyzing Growth Studies of Four Mullidae Species Distributed in Mediterranean Sea and Black Sea. Pakistan Journal of Zoology, 48(2), 435-446.

Gündoğdu, S., Baylan, M., Çevik, C. (2016). Comparative study of the Length-Weight Relationships of some fish species along the Turkish coasts. Mediterranean Marine Science, 17(1), 80-108.

Helser, T.E., Lai, H.L. (2004). A Bayesian hierarchical meta-analysis of fish growth: with an example for North American largemouth bass, Micropterus salmoides. Ecological Modelling, 178(3-4), 399-416.

Helser, T.E., Stewart, I.J., Lai, H.L. (2007). A Bayesian hierarchical meta-analysis of growth for the genus Sebastes in the eastern Pacific Ocean. Canadian Journal of Fisheries and Aquatic Sciences, 64(3), 470485.

Hilborn, R., \& Liermann, M. (1998). Standing on the shoulders of giants: learning from experience in fisheries. Reviews in Fish Biology and Fisheries, 8(3), 273-283.

Jobling, M. (1981). Temperature tolerance and the final preferendum rapid methods for the assessment of optimum growth temperatures. Journal of Fish Biology, 19(4), 439-455.

Munro, J.L., Pauly, D. (1983). A simple method for comparing the growth of fishes and invertebrates. Fishbyte, 1(1), 5-6.

Pajuelo, J.G., Lorenzo, J.M. (2004). Basic characteristics of the population dynamic and state of exploitation of Moroccan white seabream Diplodus sargus cadenati (Sparidae) in the Canarian archipelago. Journal of Applied Ichthyology, 20(1), 15-21. 
Paul, L.J. (1992). Age and growth studies of New Zealand Marine fishes, 1921-90: A review. Marine and Freshwater Research, 43(5), 879-912.

Pauly, D. (1978). A preliminary compilation of fish length growth parameters. Berichte des Institut für Meereskunde. Universität Kiel, Kiel. 200 p.

Pauly, D. (1980). On the interrelationships between natural mortality, growth parameters, and mean environmental temperature in 175 fish stocks. ICES Journal of Marine Science, 39(2), 175-192.

Pauly, D., Munro, J.L. (1984). Once more on growth comparison in fish and invertebrates. Fishbyte, 2, 21.

Pilling, G.M., Kirkwood, G.P., Walker, S.G. (2002). An improved method for estimating individual growth variability in fish, and the correlation between von Bertalanffy growth parameters. Canadian Journal of Fisheries and Aquatic Sciences, 59(3), 424-432.

Reina, J., Martinez, G., Amores, A., Alvarez, M.C. (1994). Interspecific genetic differentiation in Western Mediterranean sparid fish. Aquaculture, 125(1-2), 4757.

Sala, E., Ballesteros, E. (1997). Partitioning of space and food resources by three fish of the genus Diplodus (Sparidae) in a Mediterranean rocky infralittoral ecosystem. Marine Ecology Progress Series, 273-283.
Soykan, O., Ilkyaz, A.T., Metin, G., Kinacigil, H.T. (2015). Growth and reproduction of Boops boops, Dentex macrophthalmus, Diplodus vulgaris, and Pagellus acarne (Actinopterygii: Perciformes: Sparidae) from east-central Aegean Sea, Turkey. Acta Ichthyologica et Piscatoria, 45(1), 39.

Stergiou, K.I. (2000). Life-history patterns of fishes in the Hellenic Seas. Web Ecology, 1(1), 1-10.

Stergiou, K.I., Karachle, P.K. (2006). A review of various biological parameters for fish from the Greek Seas. Journal of Biological Research, 6, 199-211.

Summerer, M., Hanel, R., Sturmbauer, C. (2001). Mitochondrial phylogeny and biogeographic affinities of sea breams of the genus Diplodus (Sparidae). Journal of Fish Biology, 59(6), 1638-1652.

Taylor, C.C. (1958). Cod growth and temperature. ICES Journal of Marine Science, 23(3), 366-370.

Ventura, D., Jona Lasinio, G., Ardizzone, G. (2015). Temporal partitioning of microhabitat use among four juvenile fish species of the genus Diplodus (Pisces: Perciformes, Sparidae). Marine ecology, 36(4), 10131032.

Wootton, R.J. (2012). Ecology of teleost fishes (Vol. 1). Springer Science \& Business Media. ISBN: 9400908296-9789400908291 


\section{Appendix}

Biological parameters for various Diplodus stocks in various seas $\left[\mathrm{K}_{\text {in }} \mathrm{yr}^{-1}, \mathrm{~L}_{\infty}\right.$ in $\mathrm{cm}$, and $\mathrm{t}_{0}$ in $\mathrm{yr}$. Sex $(\mathrm{M}=$ males, $\mathrm{F}=\mathrm{females}, \mathrm{B}=\mathrm{combined})$. $\mathrm{N}$ denotes the number of individuals used for parameter estimation. Method denotes the method used for the estimation of age $\left(\mathrm{O}=\right.$ otoliths, $\mathrm{S}=\mathrm{scales}, \mathrm{LF}=$ length-frequencies). $\mathrm{L}_{\max }$ and $\mathrm{t}_{\mathrm{max}}$ denote maximum body length, in cm, and maximum age, in yr, respectively. LT denotes type of length used in the original study (TL=total, FL=fork,). nr: not reported.

\begin{tabular}{|c|c|c|c|c|c|c|c|c|c|c|c|c|c|c|c|}
\hline Species & Location & Country & LT & Sex & $\boldsymbol{L}_{\infty}$ & $K$ & $t_{0}$ & $t_{\max }$ & $L_{\min }$ & $L_{\max }$ & $L_{\max } / L_{\infty}$ & $\mathbf{N}$ & Method & Year & Author \\
\hline \multirow{16}{*}{ D. annularis } & \multirow{2}{*}{ Adriatic Sea } & \multirow{2}{*}{ Coratia } & $\mathrm{TL}$ & B & 23,95 & 0,13 & $-1,66$ & 13 & 3,3 & 23,0 & 0,960 & 786 & SR & $2000-2002$ & Matic-Skoko et al. (2007a) \\
\hline & & & $\mathrm{TL}$ & B & 22,60 & 0,17 & $-1,46$ & 13 & 3,3 & 20,0 & 0,885 & 1872 & SR & $2000-2002$ & Matic-Skoko et al. (2004) \\
\hline & Alexandria & Eygpt & $\mathrm{TL}$ & B & 18,10 & 0,34 & $-0,50$ & 6 & 9,0 & 17,0 & 0,939 & 466 & SR & $1980-1981$ & Wassef (1985) \\
\hline & Annaba Gulf & Algeria & $\mathrm{TL}$ & B & 19,54 & 0,46 & $-0,57$ & 6 & 12,6 & 18,8 & 0,962 & 648 & SR & $\mathrm{nr}$ & Nouacher and Djebar (2007)" \\
\hline & \multirow{3}{*}{$\begin{array}{l}\text { Canary Is- } \\
\text { lands }\end{array}$} & \multirow{6}{*}{ Spain } & $\mathrm{TL}$ & M & 24,57 & 0,26 & $-0,89$ & 6 & 8,9 & 20,6 & 0,838 & 173 & OR & 1998 & Pajuelo and Lorenzo (2002b) \\
\hline & & & $\mathrm{TL}$ & $\mathrm{F}$ & 24,96 & 0,25 & $-0,89$ & 6 & 9,4 & 20,9 & 0,837 & 139 & OR & 1998 & Pajuelo and Lorenzo (2002b) \\
\hline & & & $\mathrm{TL}$ & B & 24,79 & 0,26 & $-0,88$ & 6 & 8,2 & 20,9 & 0,843 & 194 & OR & 1998 & Pajuelo and Lorenzo (2001) \\
\hline & $\begin{array}{c}\text { Catalan } \\
\text { Coast }\end{array}$ & & $\mathrm{TL}$ & B & 20,37 & 0,54 & $-0,03$ & 7 & 9,0 & 20,0 & 0,982 & 180 & OR & $\mathrm{nr}$ & Gordoa and Moli (1997) \\
\hline & \multirow{2}{*}{$\begin{array}{l}\text { Mallorca } \\
\text { 1sland }\end{array}$} & & $\mathrm{TL}$ & $\mathrm{F}$ & 15,93 & 0,45 & $-0,12$ & 9 & 9,0 & 20,9 & 1,312 & 166 & OR & 2007 & Alos et al. (2010) \\
\hline & & & $\mathrm{TL}$ & M & 15,17 & 0,47 & $-0,07$ & 8 & 8,4 & 19,3 & 1,272 & 141 & OR & 2007 & Alos et al. (2010) \\
\hline & \multirow{3}{*}{$\begin{array}{c}\text { Edremit } \\
\text { Gulf }\end{array}$} & \multirow{4}{*}{ Turkey } & FL & M & 20,01 & 0,14 & $-2,93$ & 6 & 8,2 & 15,3 & 0,763 & 330 & OR & $1997-1998$ & Torcu-Koç et al. (2002)* \\
\hline & & & FL & $\mathrm{F}$ & 18,76 & 0,21 & $-1,73$ & 7 & 8,0 & 15,0 & 0,802 & 322 & OR & 1997-1998 & Torcu-Koç et al. (2002)* \\
\hline & & & FL & B & 22,86 & 0,25 & $-1,45$ & 4 & 8,5 & 17,0 & 0,744 & 160 & $\mathrm{LF}$ & 1997-1999 & Kınacigil and Akyol (2001)* \\
\hline & İzmir Bay & & $\mathrm{TL}$ & B & 22,01 & 0,23 & $-1,30$ & 7 & 7,7 & 18,3 & 0,831 & 2393 & OR & 2004-2007 & Kınacigil et al. (2008) \\
\hline & $\begin{array}{l}\text { Gulf of } \\
\text { Gabes }\end{array}$ & Tunusia & $\mathrm{TL}$ & B & 22,64 & 0,16 & $-2,00$ & 6 & 8,4 & 16,1 & 0,712 & $\mathrm{nr}$ & $\mathrm{LF}$ & $\mathrm{nr}$ & Bradai et al. (2001) \\
\hline & Gulf of Lion & France & FL & $\mathrm{B}$ & 18,66 & 0,56 & $-0,02$ & 5 & 3,3 & 18,2 & 0,973 & $\mathrm{nr}$ & SR & $\mathrm{nr}$ & Girardin (1978)*" \\
\hline D. bellottii & $\begin{array}{l}\text { Western Sa- } \\
\text { hara }\end{array}$ & Morocco & FL & B & 28,42 & 0,27 & $-0,19$ & & 8,9 & 20,8 & 0,733 & $\mathrm{nr}$ & LF & 1980-1982 & Mennes $(1985)^{* *}$ \\
\hline \multirow{5}{*}{ D. capensis } & \multirow[t]{2}{*}{$\begin{array}{l}\text { Tsitsikamma } \\
\text { coast }\end{array}$} & \multirow{2}{*}{$\begin{array}{l}\text { South Af- } \\
\text { rica }\end{array}$} & FL & B & 36,19 & 0,25 & $-1,05$ & 21 & 8,9 & 38,9 & 1,074 & 318 & OR & 1989-1990 & Mann and Buxton (1997)* \\
\hline & & & FL & $\mathrm{F}$ & 40,84 & 0,09 & $-4,40$ & 20 & 8,9 & 38,6 & 0,946 & 326 & OR & 2008-2009 & Richardson et al. (2011)* \\
\hline & \multirow{3}{*}{$\begin{array}{l}\text { South An- } \\
\text { gola }\end{array}$} & \multirow{3}{*}{ Angola } & FL & M & 27,70 & 0,31 & $-1,40$ & 11 & 8,9 & 29,3 & 1,059 & 64 & OR & 2008-2009 & Richardson et al. (2011)*" \\
\hline & & & FL & $\mathrm{F}$ & 25,61 & 0,45 & $-1,00$ & 10 & 8,9 & 35,0 & 1,368 & 131 & OR & 2008-2009 & Richardson et al. (2011)* \\
\hline & & & FL & M & 23,98 & 0,49 & $-0,90$ & 8 & 8,9 & 24,1 & 1,005 & 57 & OR & 2008-2009 & Richardson et al. (2011)*" \\
\hline
\end{tabular}




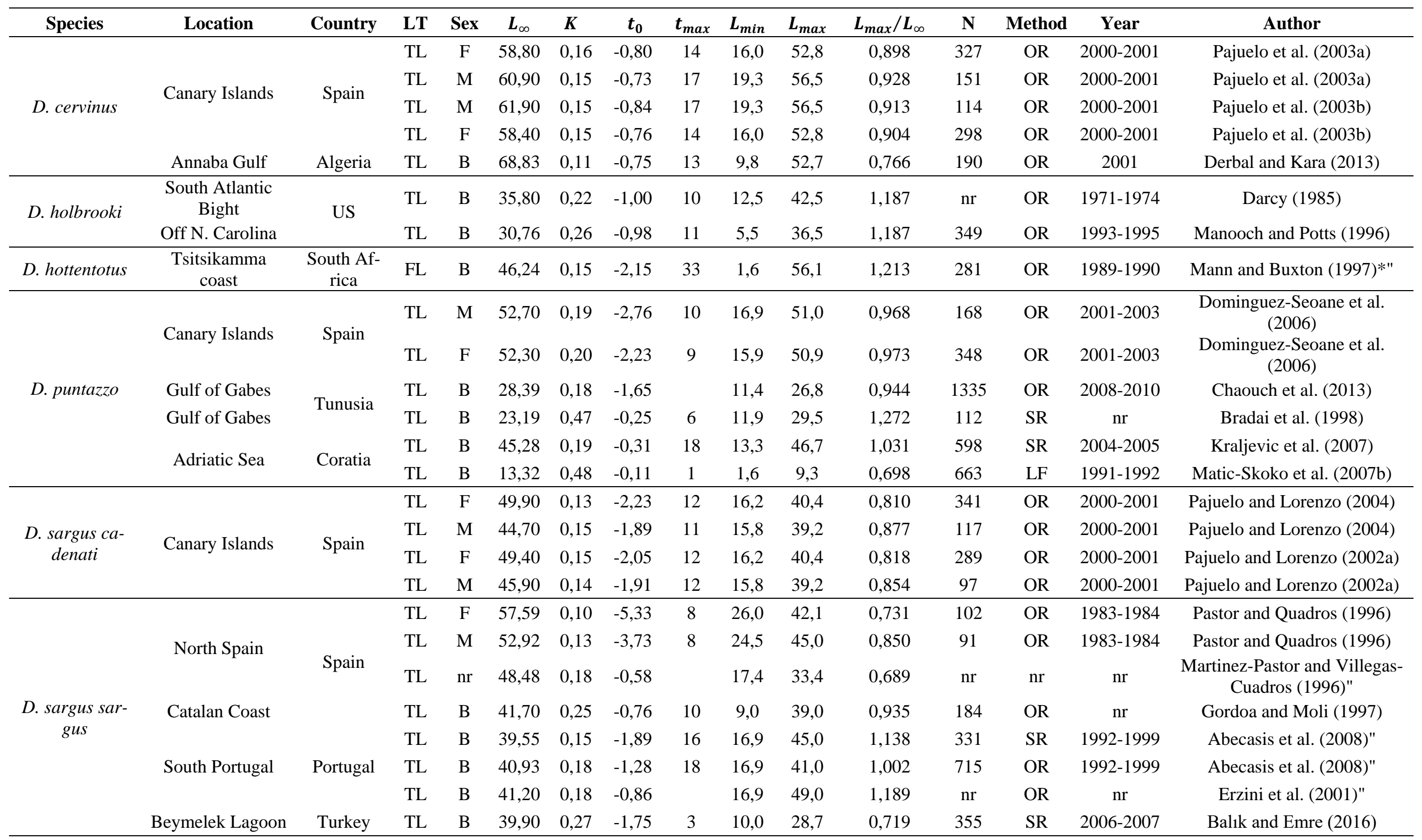




\begin{tabular}{|c|c|c|c|c|c|c|c|c|c|c|c|c|c|c|c|}
\hline Species & Location & Country & LT & Sex & $\boldsymbol{L}_{\infty}$ & $\boldsymbol{K}$ & $t_{0}$ & $t_{\max }$ & $L_{\min }$ & $L_{\max }$ & $L_{\max } / \boldsymbol{L}_{\infty}$ & $\mathbf{N}$ & Method & Year & Author \\
\hline \multirow{7}{*}{$\begin{array}{l}\text { D. sargus } \\
\text { sargus }\end{array}$} & \multirow{2}{*}{ Gulf of Lion } & \multirow{2}{*}{ France } & TL & $\mathrm{B}$ & 35,25 & 0,22 & $-0,84$ & 14 & 6,0 & 42,0 & 1,191 & 484 & SR & 1980 & Man-Wai and Quignard (1982) \\
\hline & & & FL & B & 22,86 & 0,53 & $-0,14$ & 4 & 10,0 & 42,0 & 1,837 & $\mathrm{nr}$ & SR & $\mathrm{nr}$ & Girardin (1978)*" \\
\hline & Abu Qir Bay & \multirow{4}{*}{ Eygpt } & $\mathrm{TL}$ & B & 31,30 & 0,26 & $-0,73$ & 6 & 7,5 & 27,5 & 0,879 & 746 & SR & 2008-2009 & Mahmoud et al. (2010) \\
\hline & \multirow{2}{*}{ Alexandria } & & $\mathrm{TL}$ & B & 32,70 & 0,13 & $-1,84$ & 13 & 11,2 & 39,0 & 1,193 & $\mathrm{nr}$ & SR & $\mathrm{nr}$ & LahLah (2004)" \\
\hline & & & TL & B & 54,86 & 0,10 & $-2,06$ & 8 & 11,2 & 39,0 & 0,711 & 604 & SR & 2008-2009 & El-Maghraby et al. (1981)" \\
\hline & \multirow{2}{*}{$\begin{array}{l}\text { North Sinai } \\
\text { East Algeria }\end{array}$} & & $\mathrm{TL}$ & B & 40,71 & 0,25 & $-0,28$ & 5 & 11,0 & 38,0 & 0,933 & 991 & SR & 2010-2012 & Al-Beak et al. (2015) \\
\hline & & Algeria & $\mathrm{TL}$ & B & 36,30 & 0,15 & $-0,49$ & 10 & 12,2 & 34,6 & 0,953 & 241 & OR & $2005-2006$ & Benchalel and Kara (2013) \\
\hline \multirow{23}{*}{ D. vulgaris } & \multirow{2}{*}{$\begin{array}{c}\text { Alexandria } \\
\text { Abu Qir Bay }\end{array}$} & \multirow{2}{*}{ Eygpt } & $\mathrm{TL}$ & $\mathrm{B}$ & 57,71 & 0,07 & $-2,94$ & 7 & 11,2 & 30,0 & 0,520 & 410 & SR & $2008-2009$ & El-Maghraby et al. (1981) \\
\hline & & & $\mathrm{TL}$ & B & 31,30 & 0,26 & $-0,56$ & 6 & 8,5 & 26,0 & 0,831 & 616 & SR & $1998-2008$ & Adam (2010) \\
\hline & \multirow{3}{*}{ Adriatic Sea } & \multirow{3}{*}{ Coratia } & $\mathrm{TL}$ & M & 56,25 & 0,08 & $-2,92$ & 10 & 14,5 & 37,5 & 0,667 & 1620 & SR & $2005-2006$ & Dulcic et al. (2011) \\
\hline & & & $\mathrm{TL}$ & $\mathrm{F}$ & 51,96 & 0,10 & $-2,84$ & 11 & 14,5 & 36,2 & 0,697 & 1333 & SR & $2005-2006$ & Dulcic et al. (2011) \\
\hline & & & $\mathrm{TL}$ & B & 24,14 & 0,16 & $-2,33$ & 7 & 7,0 & 25,0 & 1,036 & 1097 & SR & 2006-2007 & Hadj Taieb et al. (2013a) \\
\hline & \multirow[t]{2}{*}{ Gulf of Gabes } & \multirow{4}{*}{ Tunusia } & $\mathrm{TL}$ & B & 25,40 & 0,18 & $-1,63$ & 9 & 7,0 & 25,0 & 0,984 & 1097 & OR & $2008-2010$ & Hadj Taieb et al. (2013b) \\
\hline & & & $\mathrm{TL}$ & B & 23,47 & 0,22 & $-1,45$ & 8 & 10,8 & 32,0 & 1,363 & 97 & SR & $\mathrm{nr}$ & Bradai et al. (1998) \\
\hline & \multirow{2}{*}{$\begin{array}{l}\text { Gulf of Tunu- } \\
\text { sia }\end{array}$} & & $\mathrm{TL}$ & B & 39,90 & 0,11 & $-0,73$ & 12 & 10,0 & 32,0 & 0,802 & 510 & SR & 2005-2006 & Mouine et al. (2010) \\
\hline & & & $\mathrm{TL}$ & B & 39,00 & 0,10 & $-0,96$ & 11 & 10,6 & 32,0 & 0,821 & 492 & OR & $2005-2006$ & Mouine et al. (2010) \\
\hline & \multirow{6}{*}{ South Portugal } & \multirow{6}{*}{ Portugal } & $\mathrm{TL}$ & B & 28,10 & 0,30 & $-1,62$ & 10 & 12,5 & 30,5 & 1,085 & 374 & OR & 1992-1994 & Gonçalves (2000) \\
\hline & & & $\mathrm{TL}$ & B & 39,60 & 0,32 & $-0,48$ & & 12,5 & 30,5 & 0,770 & 374 & LF & 1992-1994 & Gonçalves (2000) \\
\hline & & & $\mathrm{TL}$ & B & 34,49 & 0,18 & $-1,27$ & 14 & 9,0 & 33,0 & 0,957 & 377 & SR & 1992-1999 & Abecasis et al. (2008) \\
\hline & & & $\mathrm{TL}$ & B & 27,40 & 0,40 & $-0,77$ & 14 & 9,0 & 30,0 & 1,095 & 1076 & $\mathrm{OR}$ & 1992-1999 & Abecasis et al. (2008) \\
\hline & & & $\mathrm{TL}$ & M & 28,60 & 0,36 & $-0,38$ & 14 & 14,5 & 36,9 & 1,290 & 368 & OR & $1992-2000$ & Gonçalves et al. (2003) \\
\hline & & & $\mathrm{TL}$ & $\mathrm{F}$ & 27,67 & 0,39 & $-0,34$ & 12 & 13,8 & 37,0 & 1,337 & 440 & OR & $1992-2000$ & Gonçalves et al. (2003) \\
\hline & \multirow{2}{*}{ Gulf of Lion } & \multirow{2}{*}{ France } & $\mathrm{TL}$ & B & 37,80 & 0,18 & $-0,83$ & 8 & 10,0 & 35,0 & 0,926 & 556 & SR & $\mathrm{nr}$ & Man Wai (1985) \\
\hline & & & FL & $\mathrm{B}$ & 30,79 & 0,26 & $-0,61$ & 3 & 9,0 & 18,2 & 0,590 & $\mathrm{nr}$ & SR & $\mathrm{nr}$ & Girardin $(1978)^{*}$ \\
\hline & \multirow{2}{*}{$\begin{array}{l}\text { Canary Islands } \\
\text { Catalan Coast }\end{array}$} & \multirow{2}{*}{ Spain } & $\mathrm{TL}$ & B & 39,70 & 0,23 & $-0,91$ & 9 & 13,0 & 37,0 & 0,932 & 488 & OR & 2000-2001 & Pajuelo and Lorenzo (2003) \\
\hline & & & $\mathrm{TL}$ & B & 28,78 & 0,39 & $-0,66$ & 6 & 8,0 & 28,0 & 0,973 & 201 & OR & $\mathrm{nr}$ & Gordoa and Moli (1997) \\
\hline & \multirow{4}{*}{$\begin{array}{l}\text { Coasts } \\
\text { Scilia Strait } \\
\text { İzmir Bay } \\
\text { Western Sa- } \\
\text { hara }\end{array}$} & Libya & $\mathrm{TL}$ & B & 33,30 & 0,11 & $-1,58$ & 8 & 11,0 & 27,0 & 0,811 & 290 & SR & 2005 & Saeid et al.. (2016) \\
\hline & & Italy & $\mathrm{TL}$ & B & 33,50 & 0,17 & $-2,59$ & & 14,0 & 27,0 & 0,806 & 603 & OR & 1997-1999 & Beltrano et al. (2003) \\
\hline & & Turkey & $\mathrm{TL}$ & B & 27,96 & 0,25 & $-1,18$ & 3 & 7,0 & 19,0 & 0,680 & 709 & OR & $2004-2007$ & Soykan et al. (2015) \\
\hline & & Morocco & FL & B & 44,85 & 0,40 & $-0,42$ & & 9,6 & 37,2 & 0,829 & $\mathrm{nr}$ & LF & 1980-1982 & Mennes (1985)*" \\
\hline
\end{tabular}

" $\mathrm{L}_{\max }, \mathrm{L}_{\min }$ or both not reported in the original study. They are assigned from Fishbase or other studies carried at same location. 


\section{Appendix References}

Abecasis, D., Bentes, L., Coelho, R., Correia, C., Lino, P. G., Monteiro, P., Erzini, K. (2008). Ageing seabreams: A comparative study between scales and otoliths. Fisheries Research, 89(1), 37-48.

Adam, A. M. S. (2010). Stock Assessment and Management of Diplodus Species In Abu Qir Bay, Alexandria, Egypt. Faculty of Sciences, Alexandria University.

Al-Beak, A.M. (2015). Population Dynamic and Stock Assesment of White Seabream Diplodus sargus (Linnaeus, 1758) in the Coast of North Siani. Fisheries and Aquaculture Journal, 06(04).

Alós, J., Palmer, M., Alonso-Fernández, A., Morales-Nin, B. (2010). Individual variability and sex-related differences in the growth of Diplodus annularis (Linnaeus, 1758). Fisheries Research, 101(1-2), 60-69.

Balik, I., Emre, Y. (2016). Population structure, lengthweight relationship and growth of white seabream, Diplodus sargus sargus (Linneaus, 1758), in Beymelek Lagoon, Turkey. Journal of Applied Ichthyology, 32(3), 602-605.

Beltrano, A., Cannizzaro, L., Vitale, S., Milazzo, A. (2003). Aspeti della biologia di Diplodus vulgaris (Pisces: Sparidae) nello stretto de Sicilia. Biol Mar Medit, 10, 287-290.

Benchalel, W., Kara, M.H. (2013). Age, growth and reproduction of the white seabream Diplodus sargus sargus (Linneaus, 1758) off the eastern coast of Algeria. Journal of Applied Ichthyology, 29(1), 64-70.

Bradai, M., Ghorbel, M., Jarboui, O., Bouain, A. (1998). Croissance de trois especes de sparidés: Diplodus puntazzo, D. vulgaris et Spondyliosoma cantharus du golfe de Gabes (Tunisie). Cahiers Options Méditerranéennes, 35, 51-56.

Bradai, M., Jarboui, O., Ghorbel, M., Bouain, A., \& El Abed, A. (2001). Age et croissance du sparaillon $D$. annularis (Téléostéens, Sparidae) du Golfe de Gabès. Rapp. Commun. Int. Mer Medit, 36, 246.

Chaouch, H., Hamida-Ben Abdallah, O., Ghorbel, M., Jarboui, O. (2013). Reproductive biology of the annular seabream, Diplodus annularis (Linnaeus, 1758), in the Gulf of Gabes (Central Mediterranean). Journal of Applied Ichthyology, 29(4), 796-800.
Darcy, G.A. (1985). Synopsis of biological data on the spottail pinfish,(Pisces: Sparidae). National Oceanic and Atmospheric Administratiort, National Marine Fisheries Service Tech. Rep. US Dept. Commerce. 19: $1-11$.

Derbal, F., Kara, M.H. (2013). Âge, croissance et reproduction du sar tambour Diplodus cervinus cervinus (Sparidae) des côtes de l'Est algérien. Cybium, 37(4), 247-254.

Domínguez-Seoane, R., Pajuelo, J.G., Lorenzo, J.M., Ramos, A.G. (2006). Age and growth of the sharpsnout seabream Diplodus puntazzo (Cetti, 1777) inhabiting the Canarian archipelago, estimated by reading otoliths and by backcalculation. Fisheries Research, 81(2-3), 142-148.

Dulčić, J., Pallaoro, A., Matić-Skoko, S., Dragičević, B., Tutman, P., Grgičević, R., Stagličić, N., Bukvić, V., Pavličević, J., Glamuzina, B., Kraljević, M. (2011). Age, growth and mortality of common two-banded seabream, Diplodus vulgaris (Geoffroy Saint-Hilaire, 1817), in the eastern Adriatic Sea (Croatian coast). Journal of Applied Ichthyology, 27(5), 1254-1258.

El-Maghraby, A.M., Botros, G.A., Hashem, M.T., Wassef, E.A. (1981). Age determination and growth studies of two sparid fish Diplodus sargus L. and Diplodus vulgaris Geoff. in the Egyptian Mediterranean waters. Bulletin of the National Institute of Oceanography and Fisheries, 7(3), 386-394.

Erzini, K., Bentes, L., Coelho, R., Correia, C., Lino, P. (2001). Fisheries biology and assessment of demersal species (Sparidae) from the South of Portugal. UE-DG, 14(98), 082.

Girardin, M. (1978). Les sparides (Pisces Teleostei) du Golfe du Lion. (PhD), Université des Sciences et Techniques du Languedoc, Montpellier.

Gonçalves, J.M.S., Bentes, L., Coelho, R., Correia, C., Lino, P.G., Monteiro, C.C., Riberio, J., Erzini, K. (2003). Age and growth, maturity, mortality and yield-perrecruit for two banded bream (Diplodus vulgaris Geoffr.) from the south coast of Portugal. Fisheries Research, 62(3), 349-359.

Gonįalves, J. (2000). Biologia pesqueira e dinâmica populacional de Diplodus vulgaris (Geoff.) e Spondyliosoma cantharus (L.)(Pisces, Sparidae) na 
costa Sudoeste de Portugal. Ph. D. Dissertation, University of Algarve, Faro, 352 pp.

Gordoa, A., Molí, B. (1997). Age and growth of the sparids Diplodus vulgaris, D. sargus and D. annularis in adult populations and the differences in their juvenile growth patterns in the north-western Mediterranean Sea. Fisheries Research, 33(1), 123-129.

Hadj Taieb, A., Ghorbel, M., Hadj Hamida, N.B., Jarboui, O. (2013). Age Estimation And Growth Pattern of Two-Banded Seabream, Diplodus vulgaris, on the Tunisian South Coast. Bulletin de la Société Zoologique de France, 138(1-4), 293-303.

Hadj Taieb, A., Ghorbel, M., Hadj Hamida, N.B., Jarboui, O. (2013). Reproductive biology, age and growth of the two-banded seabream Diplodus vulgaris (Pisces: Sparidae) in the Gulf of Gabès, Tunisia. Journal of the Marine Biological Association of the United Kingdom, 93(05), 1415-1421.

Kinacigil, H., Akyol, O. (2000). Effects on trawl selectivity of growth and reproduction in Diplodus annularis L. of Izmir Bay (Aegean Sea). Archive of Fishery and Marine Research, 49(1), 19-26.

Kınacıgil, H., İlkyaz, A., Metin, G., Ulaş, A., Soykan, O., Akyol, O., Gurbet, R. (2008). Balıkçılık yönetimi açısından Ege Denizi demersal balık stoklarının ilk üreme boyları, yaşları ve büyüme parametrelerinin tespiti. Retrieved from İzmir, Turkey: TÜBİTAK, ÇAYDAG-103Y132 nolu Proje Kesin Raporu.

Kraljević, M., Matić-Skoko, S., Dulčić, J., Pallaoro, A., Jardas, I., Glamuzina, B. (2007). Age and growth of sharpsnout seabream Diplodus puntazzo (Cetti, 1777) in the eastern Adriatic Sea. Cahiers de biologie marine, 48(2), 145-154.

Lahlah, M. (2004). Ecological studies on two fish species inhabiting coastal Seaweed meadous in Alexandria waters. $(\mathrm{PhD})$, Alexandria University, Alexandria.

Mahmoud, H.H., Osman, A.M., Ezzat, A.A., Saleh, A.M. (2010). Fisheries biology and management of Diplodus sargus sargus (Linnaeus, 1758) in Abu Qir Bay, Egypt. Egyptian Journal of Aquatic Research, 36(1), 123-131.

Mann, B., Buxton, C. (1997). Age and growth of Diplodus sargus capensis and D. cervinus hottentotus (Sparidae) on the Tsitsikamma coast, South Africa. Cybium, 21(2), 135-147.
Manooch III, C., Potts, J. (1996). Growth characteristics of the spottail pinfish, Diplodus holbrooki, off North Carolina. Journal of Elisha Mitchell Scientific Society 112(1), 7-19.

Man-Wai, R., Quignard, J.-P. (1982). Les Sars Diplodus sargus (Linne 1758) du Golfe du Lion: croissance et caracteristiques des debarquements aux criees de Sete et du Grau-du-Roi. Revue des Travaux de l'Institut des Peches Maritimes, 46(3), 173-194.

Martínez Pastor, C., Villegas Cuadros, M. (1996). Age, growth and reproduction of Diplodus sargus Linnaeus, 1758 (Sparidae) north of Spain. Boletín. Instituto Español de Oceanografia, 12(1), 65-76.

Matić-Skoko, S., Kraljević, M., Dulčić, J. (2004). Population structure of annular sea bream Diplodus annularis L. in the eastern Adriatic Sea. Paper presented at the CIESM Congress $(37 ; 2004)$.

Matić-Skoko, S., Kraljević, M., Dulčić, J., Jardas, I. (2007). Age, growth, maturity, mortality, and yield-per-recruit for annular sea bream (Diplodus annularis L.) from the eastern middle Adriatic Sea. Journal of Applied Ichthyology, 23(2), 152-157.

Matic-Skoko, S., Kraljevic, M., Dulcic, J., Pallaoro, A., Lucic, D., Glamuzina, B. (2007). Growth of juvenile sharpsnout seabream, Diplodus puntazzo (Teleostei: Sparidae) in the Kornati archipelago, Eastern Adriatic Sea. Vie et milieu, 57(1-2), 13-19.

Mennes, F. (1985). Multi species assessment of fish stocks off the western Sahara region with emphasis on the family sparidae. Fishbyte, 3(2), 5-10.

Mouine, N., Ktari, M.-H., Chakroun-Marzouk, N. (2010). Age and growth of Diplodus vulgaris (Sparidae) in the Gulf of Tunis. Cybium, 34(1), 37-45.

Nouacer, S., Djebar, A. B. (2007). Le sar Diplodus annularis (L., 1758) du golfe d'Annaba: croissances linéaire et pondérale. Rapp. Comm. int. Mer Médit, 38, 556.

Pajuelo, J., \& Lorenzo, J. (2002). Age and growth of the annular seabream, Diplodus annularis (Pisces: Sparidae), from the Canarian archipelago (central-east Atlantic). Ciencias Marinas, 28(1), 1-11.

Pajuelo, J., Lorenzo, J. (2003). The growth of the common two-banded seabream, Diplodus vulgaris (Teleostei, Sparidae), in Canarian waters, estimated by reading 
otoliths and by back-calculation. Journal of Applied Ichthyology, 19(2), 79-83.

Pajuelo, J., Lorenzo, J. (2004). Basic characteristics of the population dynamic and state of exploitation of Moroccan white seabream Diplodus sargus cadenati (Sparidae) in the Canarian archipelago. Journal of Applied Ichthyology, 20(1), 15-21.

Pajuelo, J.G., Lorenzo, J.M. (2001). Biology of the annular seabream, Diplodus annularis (Sparidae), in coastal waters of the Canary Islands. Journal of Applied Ichthyology, 17(3), 121-125.

Pajuelo, J.G., Lorenzo, J.M. (2002). Growth and age estimation of Diplodus sargus cadenati (Sparidae) off the Canary Islands. Fisheries Research, 59(1-2), 93100 .

Pajuelo, J.G., Lorenzo, J.M., Domínguez, R., Ramos, A., Gregoire, M. (2003). On the population ecology of the zebra seabream Diplodus cervinus cervinus (Lowe 1838) from the coasts of the Canarian archipelago, North West Africa. Environmental biology of fishes, 67(4), 407-416.

Pajuelo, J.G., Lorenzo, J.M., Domínguez-Seoane, R. (2003). Age estimation and growth of the zebra seabream Diplodus cervinus cervinus (Lowe, 1838) on the Canary Islands shelf (Central-east Atlantic). Fisheries Research, 62(1), 97-103.

Pastor, C.M., Cuadros, V.M.L. (1996). Edad, crecimiento y reproducci'on de Diplodus sargus Linnaeus (1758) (Sparidae) en aguas asturianas (norte de Espana). Boletin - Instituto Espanol de Oceanografia, 12, 65-76.

Richardson, T.J., Potts, W.M., Santos, C.V., \& Sauer, W.H. (2011). Comparison of the population structure and life-history parameters of Diplodus capensis (Sparidae) in exploited and unexploited areas of southern Angola. African Journal of Marine Science, 33(2), 191-201.

Saeid, A.M., Elawad, A.N., Ali, R.A. (2016). Scales Morphometry And Population Parameters of Diplodus vulgaris (Geoffroy _ Hilaire, 1817) In Benghazi Coast, Libya. Asian Journal of Science and Technology, 7(4), 2745-2749.

Soykan, O., İlkyaz, A.T., Metin, G., Kınacıgil, H.T. (2015). Growth and reproduction of Boops boops, Dentex macrophthalmus, Diplodus vulgaris, and Pagellus acarne (Actinopterygii: Perciformes: Sparidae) from east-central Aegean Sea, Turkey. Acta Ichthyologica et Piscatoria, 45(1), 39-55.

Torcu-Koc, H., Cakir, D.T., Aka, Z. (2002). Age, growth, sex-ratio, spawning season and mortality of annular bream, Diplodus annularis Linnaeus (1758)(Pisces: Sparidae) in Edremit Gulf (Aegean Sea). Pakistan Journal of Biological Sciences, 6(10), 1126-2002.

Wassef, E. (1985). Comparative biological studies of four Diplodus species (Pisces, Sparidae). Cybium, 9(2), 203-2015. 